\title{
ECOLOGIA DE HEDYOSMUM BRASILIENSE MART. EX MIQ. (CHLORANTHACEAE): SUBSÍDIO PARA CULTIVO E MANEJO SUSTENTÁVEL
}

\author{
Solange Ribas Zaniolo \\ Orientadora: Prof. Dra. Raquel Rejane Bonato Negrelle
}

\begin{abstract}
RESUMO
Considerando-se a crescente demanda de novos recursos de interesse medicinal associado ao conhecimento incipiente da biologia de espécies potencialmente medicinais, os estudos ecológicos fornecem bases para o estabelecimento de cultivo e para manejo sustentável. O objetivo deste estudo visou subsidiar a elaboração de um plano de manejo e/ou implantação de sistema de cultivo do arbusto dióico Hedyosmum brasiliense Mart. ex Miq. (Chlorantaceae). Esta tese organizada em sete capítulos que apresentam dados obtidos na Reserva Volta Velha (2604' S, 48³8' W), Mun. Itapoá, SC durante os anos de 1998, 1999 e 2000. A descrição da espécie e de aspectos geoclimáticos, edáficos e históricos deste local de estudo estão incluídos no capítulo 2. O capítulo 3 apresenta a estrutura e dinâmica da população onde foram estudados tamanho (altura e área da copa), crescimento, sobrevivência, razão sexual e definidas sete classes de tamanho baseadas na altura. A distribuição de alturas contínua e o crescimento relativamente rápido sugerem que esta espécie está regenerandose in situ e ainda, a sua alta taxa de sobrevivência revelam seu potencial para cultivo e/ou manejo sustentável. O estudo da fenologia da espécie é apresentado no capítulo 4 no qual a população de folhas, flores e frutos foram observadas em 36 indivíduos em intervalos quinzenais durante 22 meses (setembro de 1998 a julho de 2000). A espécie é perenifólia, produzindo folhas continuamente. Todos os indivíduos floresceram durante os dois anos de estudo, iniciando no mês mais seco (Agosto), a plantas masculinas iniciaram a floração cerca de um mês antes das femininas. A maturação dos frutos iniciou durante o período quente e úmido (Janeiro) e estendeu-se até 5 meses depois. Os padrões fenológicos foram similares nos dois anos de estudo, observando-se pequenas variações temporais entre os indivíduos. A produção de folhas, flores e frutos (plantas femininas) foi alta e consistente por indivíduo. O capítulo 5 teve como objetivo examinar os efeitos da qualidade de luz e umidade do substrato na germinação das sementes, o primeiro experimento consistiu de diferentes regimes de qualidade de luz (branca, vermelha, vermelha-extrema e ausência de luz) em dois níveis de umidade ( 10 e $20 \mathrm{ml}$ de água/gerbox), no segundo experimento foi manipulada a umidade sobre maior variabilidade (1/3 e 2/3 da capacidade de campo, capacidade de campo e saturação) em dois substratos (vermiculita e solo procedente do hábitat da espécie). A baixa germinação na condição de luz vermelha-extrema é uma indicação de que a espécie seja pioneira; a condição de solo saturado apesar de revelar baixa germinação não reduziu a viabilidade das sementes. 0 capítulo 6 tem como objetivo auxiliar no controle de qualidade da espécie por meio da descrição de alguns aspectos estruturais da folha. As análises anatômicas foram realizadas em folhas adultas, sendo a lâmina analisada na região mediana, ao nível da nervura central. Estômatos laterocíticos e grandes, mesofilo com parênquima paliçádico e lacunoso pouco diferenciados, presença de células epidérmicas secretoras, esclereídes, hidatódios e ductos no pecíolo constituem características próprias da espécie que podem ser usadas para testar possíveis misturas de outros produtos. O capítulo 7 apresenta um conjunto de considerações e recomendações no sentido da implementação do cultivo e manejo sustentável da espécie.
\end{abstract}

\begin{abstract}
The growing demand for' medical remedies requires better understanding of the basic ecology of plants that supply the remedies, thus providing the theoretical basis for sustainably cultivating such plants. The goals of this study were to provide ecological information for the medicinal shrub Hedyosmum brasiliense Mart. ex Miq. (Chloranthaceae). This thesis is organized in seven chapters, all based on data collected

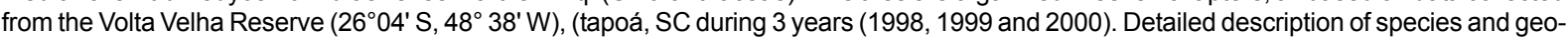
climatic, soils and historic aspects of this place is presented in the chapter 2. Chapter 3 describes population structure and dynamics: plant height, crown area, growth, survival and sex ratio were studied. The continuous distribution and relatively rapid growth indicate that this shrub is regenerating in situ with a very high annual survival rate, hence showing promise as a sustainable source of medicinal compounds. In chapter 4 the phenology of this shrub was studied during 22 months (September 1998 to July 2000). Leaf, flower and fruit production were observed in 36 randomly selected individuals. This shrub species is evergreen with constant leaf production. All individuals flowered in both years, beginning in the drier month (August), with male plants flowering about a month before female plants. Fruit maturation began during the hot and wet period (January) and the fruiting period lasted for five months. Phenological patterns in this shrub were regular, consistent among plants and over the two years of the study. In chapter 5 , humidity and light, and their possible interations, on germination rates were examined by placing seeds in two humidity regimes $(10$ and $20 \mathrm{ml} \mathrm{H} 2 \mathrm{O} / \mathrm{gerbox}$ ), and four light regimes (white, red, far-red, and dark). Possible interactions between soil type and moisture content were examined with two soil types (soil and vermiculite) and four moisture levels (1/3,2/3 and full field capacity, and saturation). Low germination rate in far red light is an indication that the plant is a pioneer species. The higher germination rates in soil at $1 / 3$ capacity suggests that additional characteristics within the soil besides moisture may be important in germination. Also, saturated soils do not reduce seed viability, which is important for plant species found in saturated soils. Leaf structures were studied in Chapter 6 to aid in quality control of this medicinal species. Anatomical analyses were of mature leaves. Lamina were analysed at the leaf center on the level of its midrib. Laterocytic and large stomata, presence of glandular epidermal cells, undiferentiaded mesophyll, sclereids, hydathodes in the lamina and ducts in the petiole are characteristics typical this species and that are useful to test the possible admixture of others products. Chapter 7 provides a synthesis of these results, in order to provide a series of considerations and recommendations for the production and sustainable use of this plant.

Key-words: structure, population dynamics, phenology, seed germination, leaf anatomy.
\end{abstract}

